\title{
Chromatographic Studies on the Tannins of Aerva lanata (L.) Juss. Ex Schultes
}

\author{
Yamuna Devi $\mathrm{M}^{1 \#}$, Wesely $\mathrm{EG}^{2}$, Johnson $\mathrm{M}^{* 3}$ \\ ${ }^{I}$ Research \& Development Department, Bharathiyar University, Coimbatore - 641 046, Tamil Nadu, India \\ ${ }^{2}$ Department of Botany, Arignar Anna Government Arts College, Namakkal - 637002. \\ ${ }^{3}$ Department of Plant Biology and Plant Biotechnology, St. Xavier's College (Autonomous), Palayamkottai, Tamil Nadu, \\ India - 627002. \\ \# Present Address: Department of Biotechnology, Dr. G. R. Damodaran College of Science, (Autonomous), Coimbatore- \\ 641 014,Tamil Nadu, India.
}

\begin{abstract}
S:
The present study was intended to establish the HPTLC tannins profile of the medicinally important plant Aerva lanata (L.) Juss. Ex Schultes. HPTLC profiling was performed out by the method described by Harborne and Wagner et al. The TolueneEthyl acetate-Formic acid-Methanol (3: 3: 0.8: 0.2) was employed as mobile phase for tannins. Linear ascending development was carried out in $20 \mathrm{~cm}$ x $10 \mathrm{~cm}$ twin trough glass chamber (Camag, Mutenz, Switzerland) saturated with the mobile phase and the chromatoplate development for two times with the same mobile phase to get good resolution of phytochemical contents. The developed plate was sprayed with $5 \%$ Ferric chloride reagent as spray reagent and dried at $100^{\circ}$ $\mathrm{C}$ in hot air oven for $10 \mathrm{~min}$. The methanolic extract of stem, leaves, root, flower and seeds of A. lanata illustrated the presence of 24 different types of tannins with 24 different Rf values with range 0.01 to 0.93 . In general, higher degree of tannins diversity has been observed in vegetative parts when compared to the reproductive parts. Maximum number (10) of tannins has been observed in flowers and seeds followed by leaves (9). The tannins with the $\mathrm{Rf}$ value 0.01 is present commonly in the aerial parts (stem, leaves and flowers \& seeds) of the plant. The tannins with the Rf values $0.53,0.67$ and 0.80 show their joint presence in stem and leaves of $A$. lanata. The results of the present study provided a valuable phytomarker for the identification and characterization of A. lanata. Further pharmacological studies are going on this plant in order to isolate, identify, characterize and elucidate the structure of the bioactive compounds.
\end{abstract}

Keywords: Tannins, Chemical Profiling, Phytoconstituents, Tannins

\section{INTRODUCTION}

Tannins are one of the major phyto-constituents found in many higher plants. Tannins are phenolic compounds present in various parts of the plants including the leaves, roots and fruits. Tannins have a characteristic strange smell and astringent taste and could bind through the effective formation of strong complexes with proteins and other macromolecules. Thus, they could have a major impact on animal nutrition, including inhibition of growth rate digestive enzymes [1]. Generally, tannins are classified into hydrolyzable tannins and condensed tannins. HTs are usually present in low quantity in plants but they are environmentally important because they are water soluble at most $\mathrm{pH}$ 's and they have a tendency to bind and seize toxic metal ions which decrease bioavailability. Tannins and related polyphenols have been implicated to various pharmacotherapeutic effects [2]. Tannins, in the form of proanthocyanidins, could have a beneficial effect on vascular health. Topical applications of tannins help to drain out all irritants from the skin. Tannins are used as astringents, stimulant, antiseptics, diuretic, wound healer, anti-ulcer, diarrhoea, constituent of triphala churna and in tanning industry [3]. Tannin can be toxic to bacteria, filamentous fungi and yeast [4]. They are useful as an anti-inflammatory agent and in the treatment of burns and other wounds based on their anti hemorrhagic and antiseptic potentials. In particular, the tannin containing remedies are in use as antihelmintics [5], antioxidants [6], anti-microbials and anti-virals [7], and for the cancer treatment [8]. Tannins are widely distributed in almost all plant foods $[9,10]$. However, the primary source of tannins as active pharmaceutical ingredients are the medicinal plants while the polyphenolic compounds themselves are not always well characterized and there exist differences in polyphenol composition among various plant species [11]. Ukoha et al [12] observed the high antimicrobial and fungistatic potentials of tannins in the ethyl acetate fraction of Samanaea saman pods. Paaver et al [13] estimated the total tannin content in distinct Quercus robur L. galls.

Aerva lanata L. is an important medicinal plant, found throughout tropical India as a common weed in fields and wasteland. Because of its reputation in folk medicine, A. lanata has become the subject of intense pharmacological and chemical studies for the last 30 years. Various studies have demonstrated its versatile pharmacological activities: anthelmintic, demulcent [14], anti-inflammatory [15], diuretic [16], expectorant, hepatoprotective [17], nephroprotective [18], anti-diabetic activity, anti- 
hyperglycaemic activity in rats [19, 20], anti-microbial, cytotoxic [21], urolithiatic [22], hypoglycemic, anti-hyperlipidaemic [23], anti-parasitic and anti-helmentic activities [24]. In order to identify the bioactive compounds responsible for the above pharmacological activities, phytochemical studies have been carried out by several workers with the report of different kinds of bioactive compounds particularly alkaloids such as: Canthin-6-one and beta-carboline, aervine [10-hydroxycanthin-6-one], methylaervine [10-methoxycanthin-6-one], aervoside [10- $\beta$-Dglucopyranosyloxycanthin-6-one] and aervolanine [3-[6methyoxy- $\beta$-carbolin-1-yl] propionic acid] from leaves of A. lanata [25]. The HPTLC studies on the glycosides, flavonoids, alkaloids, terpenoids and steroids of A. lanata were carried out by Yamuna et al [26-30]. The main constraint in the use of traditional remedies is the lack of standardization of raw material, manufacturing process and the final product. A biomarker on the other hand is a group of chemical compounds which are in addition to being unique for that plant material and also correlates with biological efficacy. So the need arises to lay standards by which the right material could be selected and incorporated into the formulation. HPTLC is a valuable tool for reliable identification because it can provide chromatographic fingerprints that can be visualized and stored as electronic images [31-35]. However, to fulfill the lacuna the present study was intended to resolve the tannins profile present in the stem, leaves, root and reproductive parts (Flower and Seed) of A. lanata, which will be useful for the proper identification of commercial samples.

\section{MATERIALS AND METHODS}

Aerva lanata was collected from natural habitats, Rasipuram, Nammakkal, Tamil Nadu, India. It was authenticated by Dr. E.G. Wesely and the voucher specimens were deposited in the St. Xavier's College Herbarium (XCH 28077) for further reference. The fresh leaves were shade dried and powdered using the electric homogenizer. The powdered samples were extracted with $150 \mathrm{~mL}$ of petroleum ether, methanol and ethyl acetate for 8-12 h by using the Soxhlet apparatus. Preliminary phytochemical screening was done by following the standard method described by Harborne [36], HPTLC studies were carried out following Wagner et al [37]. For the present study, CAMAG HPTLC system equipped with Linomat V applicator, TLC scanner 3, Reprostar 3 with 12 bit CCD camera for photo documentation, controlled by WinCATS- 4 software were used. All the solvents used for HPTLC analysis was obtained from MERCK. The samples $(5 \mu \mathrm{L})$ were spotted in the form of bands of width $5 \mathrm{~mm}$ with a Camag microlitre syringe on pre-coated silica gel glass plate $60 \mathrm{~F}-254(20 \times 10 \mathrm{~cm}$ with $250 \mu \mathrm{m}$ thickness (E. Merck, Darmstadt, Germany) using a Camag Linomat IV (Switzerland). The plates were pre-washed by methanol and activated at $60^{\circ} \mathrm{C}$ for 5 min prior to chromatography. The sample loaded plate was kept in TLC twin trough developing chamber (after saturated with solvent vapor) with respective mobile phase (tannins) and the plate was developed in the respective mobile phase up to $90 \mathrm{~mm}$. The Toluene-Ethyl acetate-Formic acid-Methanol (3: 3: 0.8: 0.2) was employed as mobile phase for alkaloids. Linear ascending development was carried out in $20 \mathrm{~cm} \times 10 \mathrm{~cm}$ twin trough glass chamber (Camag, Mutenz, Switzerland) saturated with the mobile phase and the chromatoplate development for two times with the same mobile phase to get good resolution of phytochemical contents. The optimized chamber saturation time for mobile phase was $30 \mathrm{~min}$ at room temperature $\left(25 \pm 2^{\circ} \mathrm{C}\right)$. The developed plate was dried by hot air to evaporate solvents from the plate. The developed plate was sprayed with $5 \%$ Ferric chloride reagent as spray reagent and dried at $100^{\circ} \mathrm{C}$ in hot air oven for $10 \mathrm{~min}$. The plate was photo-documented at UV $366 \mathrm{~nm}$ and daylight using Photo-documentation (CAMAG REPROSTAR 3) chamber. Finally, the plate was fixed in scanner stage and scanning was done at $366 \mathrm{~nm}$. The plate was kept in Photo-documentation chamber (CAMAG REPROSTAR3) and captured the images under White light, UV light at 254 and $366 \mathrm{~nm}$. Densitometric scanning was performed on Camag TLC scanner III and operated by CATS software (V 3.15, Camag). Blue-brown coloured zones at Day light mode were present in the tracks, it was observed from the chromatogram after derivatization, which confirmed the presence of tannin in the given standard and may be in the samples (Except Sample A).

\section{RESULTS}

Various solvent compositions of the mobile phase for HPTLC analysis were examined in order to achieve high resolution and reproducible peaks. The mobile phase with the composition of ethyl acetate-ethanol-water (8:2:1.2) showed high resolution and repeated results confirmed their efficiency and accuracy (Table 5; Fig. 1A-1K; Fig. 2A-2D). The methanolic extract of stem, leaves, root, flower and seeds of $A$. lanata illustrated the presence of 24 different types of tannins with 24 different $\mathrm{Rf}$ values with range 0.01 to 0.93 (Tables 1-5). In general, higher degree of tannins diversity has been observed in vegetative parts when compared to the reproductive parts. Maximum number (10) of tannins has been observed in flowers and seeds followed by leaves (9). Among the ten different tannins of reproductive parts (flowers and seeds), eight tannins with Rf values $0.22,0.38,0.49,0.54,0.61,0.66,0.81$ and 0.92 are unique to reproductive parts only (Table 3). Nine different types of tannins have been observed in the leaves of A. lanata. Among the nine different tannins of leaves, tannin with Rf values 0.30 , 0.63 and 0.72 are unique to the leaves and they are not present in other aerial parts of the plant. The tannins with the $\mathrm{Rf}$ value 0.93 is present commonly in all the vegetative parts of the plant. The tannins with Rf values 0.31 showed its unique presence only in the stem. The tannins of roots also showed their uniqueness by the expression $0.14,0.25,0.52,0.57,0.64$ and 0.82 in 
the tannins profile. The tannins with the Rf value 0.01 is present commonly in the aerial parts (stem, leaves and flowers \& seeds) of the plant. The tannins with the Rf values $0.53,0.67$ and 0.80 show their joint presence in stem and leaves of $A$. lanata.

\section{DISCUSSION}

The tannin compounds are widely distributed in many species of plants, where they play a role in protection from predation, perhaps also as pesticides and in plant growth regulation. Tannins are mainly physically located in the vacuoles or surface wax of plants. These storage sites keep tannins active against plant predators, but also keep some tannins from affecting plant metabolism while the plant tissue is alive; it is only after cell breakdown and death that the tannins are active in metabolic effects. Tannins are found in leaf, bud, seed, root, and stem tissues. In the present study also we observed the tannin presence in the leaves, stem, root, flower and seeds of A. lanata. Previous biological and pharmagological studies on tannins showed that tannins possess anti-inflammatory, anti-viral, anti-bacterial, anti-parasitic, anti-oxidant, anthelmintic, anti-cancer, antiseptic, anti-diuretic properties [38-47]. The results of the present study confirmed the presence of tannins stems, leaves, flowers, seeds and roots of $A$. lanata. The presence of tannin confirmed the pharmacological applications of $A$. lanata. Chromatographic fingerprint has been suggested to be practical and comprehensive approach for identifying authenticity and evaluating the quality, consistency and the stability of raw herbal materials and herbal extracts [48]. HPTLC is a valuable tool for reliable identification of the medicinally important plants [49,50]. In the present study also we established the HPTLC profile for the medicinally important plant $A$. lanata. The HPTLC profile will be used to distinguish the medicinally important plant from its adulterant.

\section{CONCLUSION}

The results of the present study provided a valuable phytomarker for the identification and characterization of A. lanata. The plants studied here are shown as a potential source of useful drugs. Further pharmacological studies are going on these plants in order to isolate, identify, characterize and elucidate the structure of the bioactive compounds. The pharmacological and biological activities of these plants for the treatments of the diseases as claimed by traditional healers are also being investigated.

\section{CONFLICT OF INTEREST STATEMENT}

We declare that we have no conflict of interest.

\section{REFERENCES}

1. A. Bennick, Interaction of plant polyphenols with salivary proteins, Crit. Rev. Oral Biol. Med., 13(2), 2002, 184196.

2. D. Ferreira, G.G. Gross, A.E. Hagerman, H. Kolodziej, and T. Yoshida T, Tannins and related polyphenols: Perspectives on their chemistry, biology, ecological effects, and human health protection, Phytochemistry, 69, 2008, 3006-3008

3. http://en.wikipedia.org/wiki/Tannin

4. J.B. Harbone, Phytochemical Methods-A Guide to Modern Techniques of Plant Analysis, Chapman and Hall, London, 1998, pp. 182-190.

5. J.K. Ketzis, J. Vercruysse, B.E. Stromberg, M. Larsen, S. Athanasiadou, and J.G. Houdijk, Evaluation of efficacy expectations for novel and non-chemical helminth control strategies in ruminants, Vet. Parasitol., 139, 2006, 321335.

6. V. Koleckar, K. Kubikova, Z. Rehakova, K. Kuca, D. Jun, L. Jahodar, and L. Opletal, Condensed and hydrolysable tannins as antioxidants influencing the health. Mini. Rev. Med. Chem., 8, 2008, 436-447.

7. P. Buzzini, P. Arapitsas, M. Goretti, E. Branda, B. Turchetti, P. Pinelli, F. Ieri, and A. Romani, Antimicrobial and antiviral activity of hydrolysable tannins, Mini. Rev. Med. Chem., 8, 2008, 1179-1187.

8. K.T. Chung, T.Y. Wong, C.I. Wei, Y.W. Huang, and Y. Lin, Tannins and human health: a review, Crit. Rev. Food Sci. Nutr., 38(6), 1998, 421-464.

9. J. Serrano, R. Puupponen-Pimia, A. Dauer, A.M. Aura, and F. Saura-Calixto, Tannins: Current knowledge of food sources, intake, bioavailability and biological effects, Mol. Nutr. Food Res., 53(S2), 2009, S310-329.

10. C. Manach, A. Scalbert, C. Morand, C. Remesy, and L. Jimenez, Polyphenols: Food sources and bioavailability, Am. J. Clin. Nutr., 79, 2004, 727-747. 
11. T. Okuda, Systematics and health effects of chemically distinct tannins in medicinal plants, Phytochemistry, 66, 2005, 2012-2031.

12. P.O. Ukoha, E.A.C. Cemaluk O.L. Nnamdi, and E.P. Madus, Tannins and other phytochemical of the Samanaea saman pods and their antimicrobial activities, African Journal of Pure and Applied Chemistry, 5(8), 2011, 237-244.

13. U. Paaver, V. Matto, and A. Raal, Total tannin content in distinct Quercus robur L. galls, Journal of Medicinal Plants Research, 4(8), 2010, 702-705.

14. A. Krishnamurthi, The Wealth of India, Vol. I, A Publication and Information Directorate. Council of Scientific and Industrial Research, New Delhi, 2003, pp. 92.

15. T. Pullaiah, and C.K. Naidu, Antidiabetic Plants in India and Herbal Based Anti-diabetic Research. New Delhi: Regency Publications, 2003, p.68-69.

16. T. Vertichelvan, M. Jegadeesan, S. Senthil Palaniappan, N.P. Murali, and K. Sasikumar, Diuretic and antiinflammatory activities of Aerva lanata in rats, Indian J. Pharm. Sci., 62, 2000, 300-302.

17. M. Udupihille, and M.T.M. Jiffry, Diuretic effect of Aerva lanata with water, normal saline and coriander as controls, Indian J Physiol and Pharmacol., 30, 1986, 91-97.

18. S. Manokaran, A. Jaswanth, S. Sengottuvelu, J. Nandhakumar, R. Duraisamy, D. Karthikeyan, and R. Mallegaswari, Hepatoprotective Activity of Aerva lanata Linn. Against Paracetamol Induced Hepatotoxicity in Rats, Research J. Pharm. and Tech., 1(4), 2008, 398-400.

19. A. Shirwaikar, D. Issac, and S. Malini, Effect of Aerva lanata on cisplatin and gentamicin models of acute renal failure, J. Ethnopharmacol., 90, 2004, 81-86.

20. T. Vetrichelvan, and M. Jegadeesan, Anti-diabetic activity of alcoholic extract of Aerva lanata [L.] Juss. Ex Schultes in rats, J. Ethnopharmacol., 80, 2002, 103-107.

21. T. Deshmukh, B.V. Yadav, S.L. Badole, S.L. Bodhankar, and S.R. Dhaneshwar, Antihyperglycaemic activity of alcoholic extract of Aerva lanata [L.] A. L. Juss. Ex J. A. Schultes leaves in alloxan induced diabetic mice, J. Appl. Biomed., 6, 2008, 81-87.

22. C. Dulaly, Antimicrobial activity and cytotoxicity of Aerva lanata, Fitoterapia, 73, 2002, 92-94.

23. G. Appia Krishnan, V.K. Rai, B.C. Nandy, K.C. Meena, S. Dey, P.K. Tyagi, and L.K. Tyagi, Hypoglycemic and Antihyperlipidaemic Effect of Ethanolic Extract of Aerial Parts of Aerva lanata Linn. in Normal and Alloxan induced Diabetic Rats, IJPSDR, 1(3), 2009, 191-194.

24. D. Anantha, T. Israiel Kumar, M. Santosh kumar, A. Manohar Reddy, N.S.V. Mukharjee, and A. Lakshmana Rao, In vitro Anti helmentic Activity of aqueous and alcoholic extracts of Aerva lanata Seeds and leaves, J. Pharm. Sci. \& Res., 2(5), 2010, 317-321.

25. G. Zapesochnaya, Canthin-6-one and beta-carboline alkaloids from Aerva lanata, Planta Medica, 58, 1992, 192196.

26. M. Yamunadevi, E.G. Wesely, and M. Johnson, Phytochemical studies on the terpenoids of medicinally important plant Aerva lanata L. using HPTLC, Asian Pacific Journal of Tropical Biomedicine, 2011, S220-S225.

27. M. Yamunadevi, E.G. Wesely, and M. Johnson, Chromatographic fingerprint analysis on flavonoids constituents of the medicinally important plant Aerva lanata L. by HPTLC technique, Asian Pacific Journal of Tropical Biomedicine, 2012, S8-S12.

28. M. Yamunadevi, E.G. Wesely, and M. Johnson, Chemical Profile Studies on the Alkaloids of medicinally important plant Aerva lanata L. using HPTLC, Journal of Natura Conscientia, 2(2), 2011, 341-349.

29. M. Yamunadevi, E.G. Wesely, and M. Johnson, A Chromatographic Study on the Glycosides of Aerva lanata L., Chinese Journal of Natural Medicines, 9(3), 2011, 210-214.

30. M. Yamunadevi, E.G. Wesely, and M. Johnson, Chromatographic finger print analysis of steroids in Aerva lanata L by HPTLC technique, Asian Pacific Journal of Tropical Biomedicine, 2011, 428-433.

31. T. Rajkumar, and B.N. Sinha, Chromatographic finger print analysis of budmunchiamines in Albizia amara by HPTLC technique, Int. J. Res. Pharm. Sci., 1(3), 2010, 313-316.

32. A. Manikandan, and A. Victor Arokia Doss, Evaluation of biochemical contents, nutritional value, trace Elements, SDS-PAGE and HPTLC profiling in the leaves of Ruellia tuberosa L. and Dipteracanthus patulus [Jacq.]., J. Chem. Pharm. Res., 29(3), 2010, 295-303. 
33. A.K. Tripathi, R.K. Verma, A.K. Gupta, M.M. Gupta, and S.P.S. Khanuja, Quantitative Determination of Phyllanthin and Hypophyllanthin in Phyllanthus Species by High-performance Thin Layer Chromatography, Phytochem. Anal., 17, 2006, 394-397.

34. V. Ramya, V. Dheena Dhayalan, and S. Umamaheswari, In vitro studies on antibacterial activity and separation of active compounds of selected flower extracts by HPTLC, J. Chem. Pharm. Res., 2(6), 2010, 86-91.

35. A.G. Patil, S.P. Koli, D.A. Patil, and N. Chandra, Phamacognostical standardization and HPTLC finger print of Crataeva tapia Linn. SSP. Odora [Jacob.] Almeida leaves, International Journal of Pharma and Biosciences, 1(2), 2010, 1-14.

36. J.B. Harborne, Phytochemcial methods, 3rd Ed., London: Chapman and Hall, 1998.

37. H. Wagner, S. Baldt, and E.M. Zgainski, Plant Drug Analysis, Berlin: Springer, 1996.

38. http://www.pharmaxchange.info

39. Y.P.S. Bajaj, Medicinal and aromatic plants: Biotechnology in agriculture and forestry, Berlin: Springer-Verlag, 1988, p. 24.

40. L. Lu, S.W. Liu, S.B. Jiang, and S.G. Wu, Tannin inhibits HIV-1 entry by targeting gp41, Acta Pharmacol. Sin., 25(2), 2004, 213-218.

41. H. Akiyama, K. Fujii, O. Yamasaki, T. Oono, and K. Iwatsuki, Antibacterial action of several tannins against Staphylococcus aureus, J. Antimicrob. Chemother., 48(4), 2001, 487-491.

42. H. Kolodziej, and A.F. Kiderlen, Antileishmanial activity and immune modulatory effects of tannins and related compounds on Leishmania parasitised RAW 264.7 cells, Phytochemistry, 66(17), 2005, 2056-2071.

43. S.M.C. Souza, L.C. Aquino, A.C. Milach Jr., M.A. Bandeira, M.E. Nobre, and G.S. Viana, Antiinflammatory and antiulcer properties of tannins from Myracrodruon urundeuva Allemão (Anacardiaceae) in Rodents, Phytotherapy Research, 21(3), 2006, 220-225.

44. F. Kurosoki, and A. Nishi, Isolation and antimicrobial activity of the phytoalexin-6-methoxymellein from cultured carrot cells, Phytochemistry, 22(3), 1983, 669-672.

45. J.B. Harborne, Photochemical Methods: A guide to modern techniques of plant analysis, Chapman and Hall, London, 1973, p. 279.

46. A.O. Adebajo, C.O. Adewumi, and E.E. Essein, Anti-infective agents of higher plants, International symposium of Medicinal Plants, $5^{\text {th }}$ Ed., University of Ife, Nigeria, 1983, pp. 152-158.

47. A. Banso, and S.O. Adeyemo, Evaluation of antibacterial properties of tannins isolated from Dichrostachys cinerea, African Journal of Biotechnology, 6(15), 2007, 1785-1787.

48. K. Koll, E. Reich, A. Blatter, and M. Veit, Validation of Standardized High-Performance Thin-Layer Chromatographic Methods for Quality Control and Stability Testing of Herbals, J of AOAC International, 86(5), 2003, 909-915.

49. S. Sampathkumar, and N. Ramakrishnan, Chromatographic finger print analysis of Naringi crenulata by HPTLC technique, Asian Pacific Journal of Tropical Biomedicine, 2011, S195-S198.

50. S.U. Rakesh, V.R. Salunkhe, P.N. Dhabale, and K.B. Burade, HPTLC Method for Quantitative Determination of Gallic Acid in Hydroalcoholic Extract of Dried Flowers of Nymphaea stellata Willd., Asian J. Research Chem., 2(2), 2009, 131-134. 
IOSR Journal of Pharmacy

Vol. 2, Issue 1, Jan-Feb.2012, pp. 041-051

Table - 1: HPTLC - Tannin profile of the Methanolic extracts of Aerva lanata Root (Sample A)

\begin{tabular}{|c|c|c|c|c|}
\hline Peak & $\mathbf{R f}$ & Height & Area & Assigned substance \\
\hline Standard & 0.45 & 457.7 & 17306.0 & Gallic acid \\
\hline 1 & 0.06 & 26.3 & 515.2 & Unknown \\
\hline 2 & 0.14 & 11.6 & 189.1 & Unknown \\
\hline 3 & 0.25 & 14.2 & 274.9 & Unknown \\
\hline 4 & 0.52 & 25.8 & 895.8 & Unknown \\
\hline 5 & 0.57 & 33.2 & 678.7 & Unknown \\
\hline 6 & 0.64 & 44.4 & 1655.5 & Unknown \\
\hline 7 & 0.82 & 122.2 & 7576.7 & Unknown \\
\hline 8 & 0.93 & 352.6 & 20988.8 & Unknown \\
\hline
\end{tabular}


IOSR Journal of Pharmacy

Vol. 2, Issue 1, Jan-Feb.2012, pp. 041-051

Table - 2: HPTLC - Tannin profile of the Methanolic extracts of Aerva lanata Stem (Sample B)

\begin{tabular}{|l|l|l|l|l|}
\hline Peak & Rf & Height & Area & Assigned substance \\
\hline 1 & 0.01 & 44.5 & 299.6 & Unknown \\
\hline 2 & 0.06 & 83.0 & 1299.5 & Tannin 1 \\
\hline 3 & 0.31 & 23.4 & 519.8 & Unknown \\
\hline 4 & 0.53 & 33.3 & 926.4 & Unknown \\
\hline 5 & 0.67 & 48.9 & 2485.7 & Unknown \\
\hline 6 & 0.80 & 121.3 & 6846.6 & Unknown \\
\hline 7 & 0.93 & 372.6 & 23087.9 & Unknown \\
\hline
\end{tabular}

Table - 3: HPTLC - Tannin profile of the Methanolic extracts of Aerva lanata Leaves (Sample C)

\begin{tabular}{|l|l|l|l|l|}
\hline Peak & Rf & Height & Area & Assigned substance \\
\hline 1 & 0.01 & 44.2 & 165.9 & Unknown \\
\hline 2 & 0.06 & 62.5 & 959.8 & Tannin 1 \\
\hline 3 & 0.30 & 15.0 & 220.5 & Unknown \\
\hline 4 & 0.53 & 45.3 & 1414.3 & Unknown \\
\hline 5 & 0.63 & 63.0 & 3509.9 & Unknown \\
\hline 6 & 0.67 & 67.0 & 1955.2 & Unknown \\
\hline 7 & 0.72 & 70.8 & 2027.5 & Unknown \\
\hline 8 & 0.80 & 117.3 & 5014.4 & Unknown \\
\hline 9 & 0.93 & 397.4 & 25329.2 & Unknown \\
\hline
\end{tabular}


IOSR Journal of Pharmacy

Vol. 2, Issue 1, Jan-Feb.2012, pp. 041-051

Table - 4: HPTLC - Tannin profile of the Methanolic extracts of Aerva lanata flowers and seeds (Sample D)

\begin{tabular}{|c|c|c|c|c|}
\hline Peak & Rf & Height & Area & Assigned substance \\
\hline 1 & 0.01 & 18.5 & 73.0 & Unknown \\
\hline 2 & 0.06 & 56.0 & 923.3 & Unknown \\
\hline 3 & 0.22 & 37.8 & 1285.1 & Unknown \\
\hline 4 & 0.38 & 252.9 & 5830.5 & Tannin 1 \\
\hline 5 & 0.49 & 37.2 & 1305.3 & Unknown \\
\hline 6 & 0.54 & 256.2 & 5578.7 & Tannin 2 \\
\hline 7 & 0.61 & 33.1 & 582.7 & Unknown \\
\hline 8 & 0.66 & 47.7 & 1952.7 & Unknown \\
\hline 9 & 0.81 & 112.1 & 7259.1 & Unknown \\
\hline 10 & 0.92 & 341.5 & 20509.1 & Unknown \\
\hline
\end{tabular}


IOSR Journal of Pharmacy

Vol. 2, Issue 1, Jan-Feb.2012, pp. 041-051

Table - 5: HPTLC - Tannin profile of the Methanolic extracts of Aerva lanata

\begin{tabular}{|c|c|c|c|c|}
\hline Rf- Value & Root & Stem & Leaves & $\begin{array}{l}\text { Flowers \& } \\
\text { Seed }\end{array}$ \\
\hline 0.01 & & + & + & + \\
\hline 0.06 & + & & + & + \\
\hline 0.14 & + & & & \\
\hline 0.22 & & & & + \\
\hline 0.25 & + & & & \\
\hline 0.30 & & & + & \\
\hline 0.31 & & + & & \\
\hline 0.38 & & & & + \\
\hline 0.49 & & & & + \\
\hline 0.52 & + & & & \\
\hline 0.53 & & + & + & \\
\hline 0.54 & & & $\lambda$ & + \\
\hline 0.57 & + & & & \\
\hline 0.61 & & & & + \\
\hline 0.63 & & & + & \\
\hline 0.64 & + & & R & \\
\hline 0.66 & & & & + \\
\hline 0.67 & & + & + & \\
\hline 0.72 & & & + & \\
\hline 0.80 & & + & + & \\
\hline 0.81 & & & & + \\
\hline 0.82 & + & & & \\
\hline 0.92 & & & & + \\
\hline 0.93 & + & + & + & \\
\hline
\end{tabular}




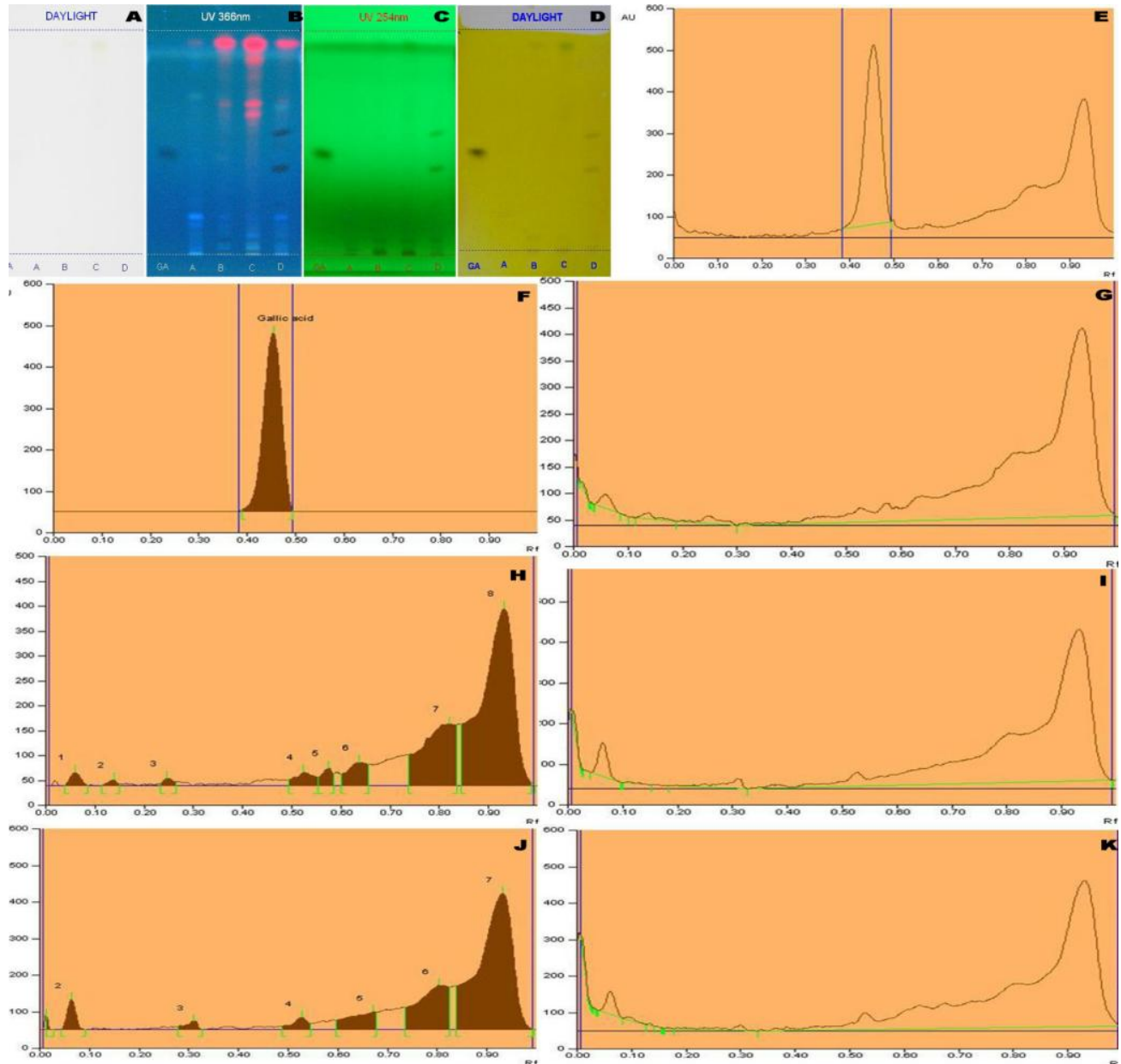

Fig. 1. HPTLC Studies on the Tannins of the medicinally important plant

Aerva lanata L. - Vegetative and Reproductive Parts

A. HPTLC profile of the methanolic extract of Aerva lanata under Daylight

B. HPTLC profile of the methanolic extract of Aerva lanata under UV 366

C. HPTLC profile of the methanolic extract of Aerva lanata under UV 254

D. HPTLC profile of the methanolic extract of Aerva lanata under Day Light - After Derivation

E. HPTLC Chromatogram of Standard Gallic acid [Scanned at 500nm]

F. HPTLC Chromatogram of standard Gallic acid Peak densitogram display [Scanned at $500 \mathrm{~nm}$ ]

G. HPTLC Chromatogram of Aerva lanata Root - Baseline display [Scanned at $500 \mathrm{~nm}$ ]

H. HPTLC Chromatogram of Aerva lanata Root - Peak densitogram display [Scanned at $500 \mathrm{~nm}]$

I. HPTLC Chromatogram of Aerva lanata Stem - Baseline display [Scanned at $500 \mathrm{~nm}$ ]

J. HPTLC Chromatogram of Aerva lanata Stem - Peak densitogram display [Scanned at $500 \mathrm{~nm}]$

K. HPTLC Chromatogram of Aerva lanata Leaves - Baseline display 

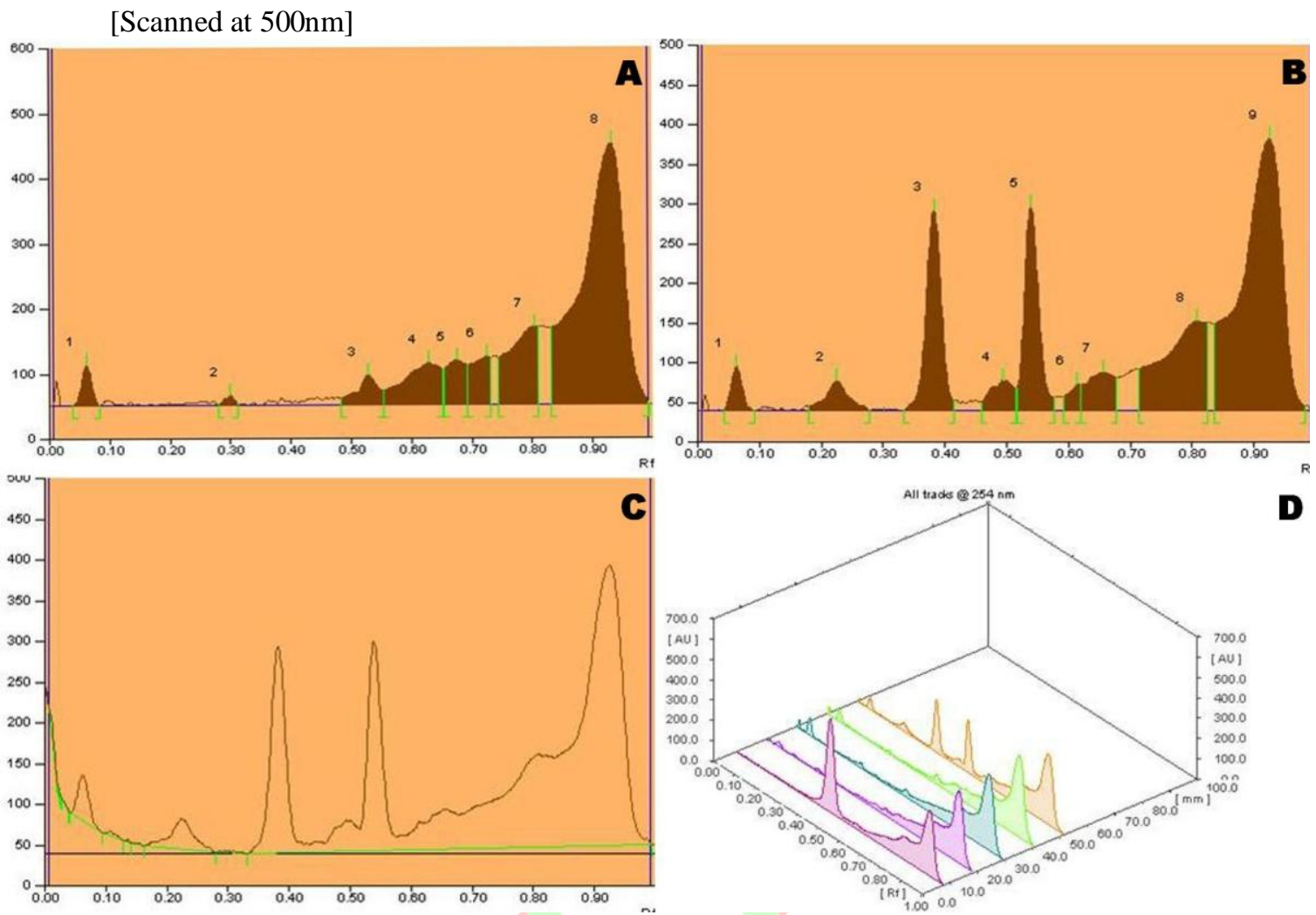

Fig. 2. HPTLC Studies on the Tannins of the medicinally important plant Aerva lanata L. - Leaves, Flowers and Seeds

A. HPTLC Chromatogram of Aerva lanata Leaves - Peak densitogram display [Scanned at 500nm]

B. HPTLC Chromatogram of Aerva lanata Flowers and Seeds - Peak densitogram display [Scanned at 500nm]

C. HPTLC Chromatogram of Aerva lanata Flowers and Seeds - Baseline display [Scanned at 500nm]

D. 3D display of HPTLC Chromatogram of Aerva lanata - Root, Stem,

Leaves, Flower and Seeds 